\title{
PULPAL TEMPERATURE INCREASE WITH HIGH-SPEED HANDPIECE, ER:YAG LASER AND ULTRASOUND TIPS
}

\author{
Fernanda Brandão MOLliCA ${ }^{1}$, Fernanda Pelogia CAMARGO ${ }^{2}$, Sandra Costa ZAMBONI ${ }^{3}$, Sarina Maciel Braga PEREIRA \\ Symone Cristina TEIXEIRA ${ }^{4}$, Lafayette NOGUEIRA JUNIOR ${ }^{5}$
}

\author{
1- DDS, Master's degree student, Department of Restorative Dentistry, São Paulo State University, São Paulo, Brazil. \\ 2- DDS, MSc, PhD student, Department of Dental Materials and Prosthodontics, São Paulo State University, São Paulo, Brazil. \\ 3- DDS, MSc, Master's degree student, Department of Dental Materials and Prosthodontics, São Paulo State University, São Paulo, Brazil. \\ 4- DDS, MSc, PhD, Assistant Professor, Department of Pediatric Dentistry, São Paulo State University, São Paulo, Brazil. \\ 5- DDS, MSc, PhD, Assistant Professor, Department of Dental Materials and Prosthodontics, São Paulo State University, São Paulo, Brazil. \\ Corresponding address: Dra. Fernanda Pelógia - Av. Cel. Alcântara, 666 - Caçapava - SP - Brazil - 12281-590 - Phone (12) 3655-5545 \\ e-mail: fernandapelogia@hotmail.com
}

Received: August 27, 2007 - Modification: October 2, 2007 - Accepted: March 1, 2008

\begin{abstract}
$\Gamma_{\text {h }}$

he aim of this study was to compare intrapulpal temperature increase produced by high-speed handpiece, Er:YAG laser and CVDentus ultrasound tips during cavity preparation. Thirty bovine mandibular incisors with an enamel/dentin thickness of 4 $\mathrm{mm}$ at buccal surface had their roots amputated and were allocated to the following groups ( $\mathrm{n}=10)$ : Group I- high-speed handpiece; Group II- noncontact Er:YAG laser $(250 \mathrm{~mJ} / 4 \mathrm{~Hz})$; and Group III- CVDentus ultrasouns tips. All devices were used with water cooling. Class $\mathrm{V}$ cavities were prepared to a depth of $3.5 \mathrm{~mm}$, measured with a periodontal probe. A type $\mathrm{T}$ thermocouple was placed inside the pulp chamber to determine the temperature increase $\left({ }^{\circ} \mathrm{C}\right)$, which was recorded by a data acquisition system ADS 2000 IP (Lynx Technology) linked to a notebook computer. Data were analyzed statistically by oneway ANOVA and Tukey's test $(\mathrm{p}=0.05)$. The mean temperature rises were: $1.10^{\circ} \mathrm{C}( \pm 0.56)$ for Group I, $0.84^{\circ} \mathrm{C}( \pm 0.55)$ for Group II, and $3.00^{\circ} \mathrm{C}( \pm 1.34)$ for Group III. There were no statistically significant differences $(\mathrm{p}>0.05)$ between Groups I and II, but both of them differed significantly from Group III $(\mathrm{p}<0.05)$. In conclusion, the use of Er:YAG laser and high-speed handpiece for cavity preparation resulted in similar temperature increase. Although ultrasound tips generated significantly higher intrapulpal temperature increase, it remained below the critical value of $5.5^{\circ} \mathrm{C}$ and may be considered safe for use.
\end{abstract}

Key words: Dental Pulp. Dental cavity preparation.

\section{INTRODUCTION}

During cavity preparation and caries removal, some care is necessary to avoid thermally induced damage to pulpal tissues because teeth undergoing an intrapulpal temperature rise of $5.5^{\circ} \mathrm{C}$ can be irreversibly damaged ${ }^{31}$. Moreover, the irritating noise, uncomfortable vibration and pain during cavity preparation with high-speed handpieces are unpleasant for the patients. These disadvantages led to the search for new techniques for hard dental tissue removal, such as lasers and ultrasound tips, which would make treatment less painful to patients, with no need of local anesthesics ${ }^{15,33}$.

Lasers may be an alternative tooth preparation method, as there is no mechanical vibration and good patient acceptance is $\operatorname{good}^{5,10,16,18}$. Each laser has specific characteristics and properties. The effect of irradiation on target tissue is largely dependent on laser wavelength and tissue absorption. When laser energy reachs a tissue surface, it can be reflected, transmitted or absorbed. The changes in tissue are largely due to the absorbed energy, which is a thermal process ${ }^{1}$. Lasers have been studied for use in dentistry since the $1960 \mathrm{~s}^{8,23}$ and $\mathrm{CO}_{2}$ and $\mathrm{Nd}$ :YAG lasers were the first to be used in dental applications, although they presented unacceptable results with respect to heat generation. Er:YAG laser has been investigated since the end of 1980s and, because of its mechanical ablation process by microexplosion, it has offered new perspectives for enamel and dentin removal without significant adverse thermal effects ${ }^{12,14,32}$.

The major part of the Er:YAG laser energy is absorbed by water molecules that induce fast heating and vaporization followed by volume expansion and explosion ${ }^{20}$. This photothermo-mechanical ablation process is most effective for dental hard tissue removal with minimal heat transfer to adjacent tissues ${ }^{22}$. Hibst \& Keller ${ }^{12}$ found that Er:YAG laser offered high ablation efficiency and low thermal side effects. Nevertheless, some studies showed that Er:YAG laser has 
some thermal effects ${ }^{2,7,13,24,34}$, and further studies are needed to verify its effect on dental pulp, as this information is lacking in the literature ${ }^{7}$.

Ultrasound has existed for over 50 years. However, its use for cavity preparation showed deficiencies such as, inefficient removal of carious tissue and slow cutting ${ }^{17}$. Diamond tips capable of being coupled to ultrasound appliances have been developed by researchers from the Brazilian National Institute of Space Research (INPE) in São José dos Campos, SP. These tips, called CVDentus (Chemical Vapor Deposition), are produced in a reactor, in which a mixture of methane and hydrogen gases results in the formation of a single artificial diamond layer on the substrate, without space between the grains. According to the manufacturer, this new technique allows the diamond to adhere to the metal rod sufficiently to bear the vibration of ultrasound, offering the advantage of a greater durability.

The CVDentus tips cut by vibration and are available in different shapes, such as truncated cone, cylindrical, spherical, inverted truncated cone and wedge-shaped (Figure 1). An important characteristic is that all tips have the same connecting rod, which means that they are universal and can be used in a wide array of ultrasound devices by means of adapters. Their indications for use vary according to their shape, and they can be used for minimally invasive dental procedures as well as for all types of cavities according to Black's cavity preparation classification system. These tips can also be used for gingival peeling, cutting of bone tissue during surgery and endodontic surgery.

According to the manufacturer, some of the advantages of using these tips for cavity preparation are their cutting accuracy, excellent finishing quality, less heat generation and absence of pain. However, there are no data available with regard to the thermal effects of ultrasound tips.

Because of the risk of thermal aggression to the pulp during cavity preparation as a result of the heat generated during the procedure ${ }^{3,24,27,29,34}$ and in view of the variety of currently available cavity preparation techniques, the aim of this study was to compare intrapulpal temperature increase produced by high-speed handpiece, Er:YAG laser and CVDentus ultrasound tips during the preparation of bovine teeth.

\section{MATERIAL AND METHODS}

Thirty bovine mandibular incisors from ten 3-year-old animals were extracted and cleaned with periodontal curettes. The roots were removed with a low-speed diamond saw to facilitate placing the thermocouples in the pulp chamber, and the crowns were immediately immersed in distilled water and further frozen $\left(-18^{\circ} \mathrm{C}\right)$.

After $24 \mathrm{~h}$, the teeth were defrosted and radiographs were taken in the mesiodistal direction to standardize tooth thickness at the buccal surface, at which cavities should be prepared. Only teeth with thickness of $4 \mathrm{~mm}$ in the cervical region of the buccal surface of the crown, as measured with a millimeter ruler in the radiographs, were used.

Thermocouples were placed inside the pulp chamber adjacent to this area and their position was confirmed radiographically. The pulp chamber was then filled with heat conductor paste (Implastec, Votorantim Indústria Brasileira, São Paulo, SP, Brazil). The apertures resulting from root removal were sealed with cement (Cavit; ESPE, Seefield, Germany) and each tooth and thermocouple wire were partially embedded in silicone (Optosil P Comfort, Heraeus Kulzer, Hanau, Germany), so that only the buccal surface remained exposed ${ }^{4}$. The purpose of these procedures was to immobilize the thermocouple and to provide a steady base for the dental crown during cavity cavities and temperature variation measurements.

The crowns were assigned to the following groups: Group I, high-speed handpiece; Group II, noncontact Er:YAG laser; and Group III, CVDentus ultrasound tips. All devices were used with water cooling. In order to standardize cavity size, in the groups prepared with high-speed burs and ultrasound tips, an adhesive tape strip was attached to the cervical region of the crowns (General Purpose Scotch, 3M, Sumaré, São Paulo, SP, Brazil). The tape had a rectangular perforation in the central region with $2 \mathrm{~mm}$ in the occlusocervical direction of the crown and $3 \mathrm{~mm}$ in the mesiodistal direction. The laser-prepared cavities were of the same size, but standardization was done by demarcating the dental enamel with a pencil, without using adhesive tape. Standard class V cavities $(2.0 \times 3.0 \mathrm{~mm})$ were performed on the buccal surfaces within 3 min by the same operator, using the method established for each of the groups.

A handpiece with 3 cooling apertures (Super-Torque 625, Kavo, Joinville, Santa Catarina, Brazil) was used for Group I.
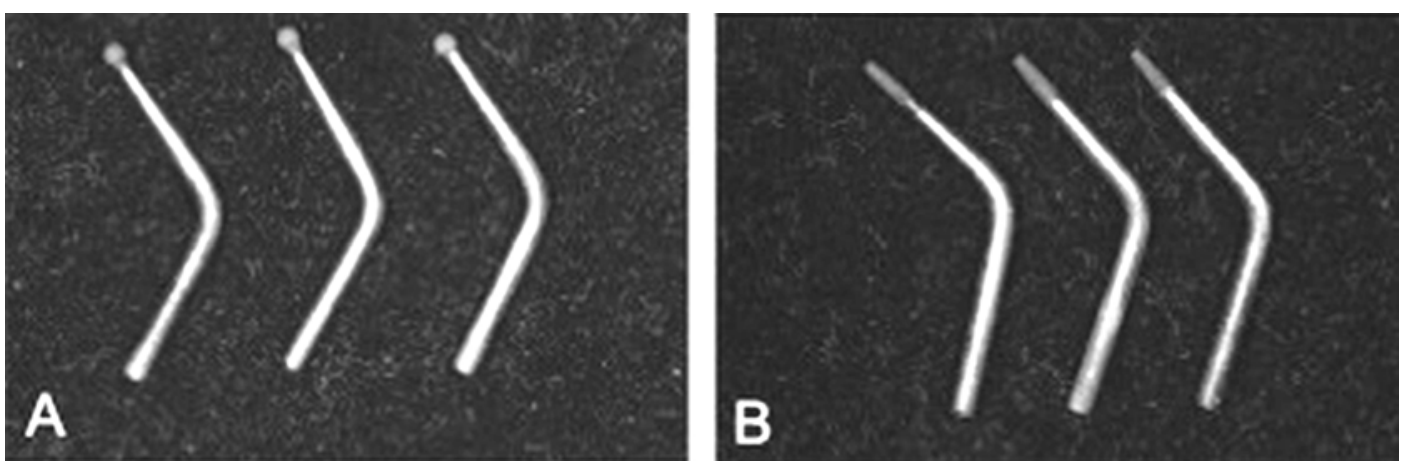

Figure 1- Different types of CVD ultrasound tips. A- Spherical. B- Truncated cone 
TABLE 1- Mean temperature increases and Tukey test $\left({ }^{\circ} \mathrm{C}\right)$ for the experimental groups

\begin{tabular}{llc}
\hline Groups & mean $\pm \mathbf{s d}\left({ }^{\circ} \mathbf{C}\right)$ & Homogeneous groups* \\
\hline High speed bur & $1.10 \pm 0.56$ & $\mathrm{~A}$ \\
Er:YAG Laser & $0.84 \pm 0.55$ & $\mathrm{~A}$ \\
CVDentus ultrasound tips & $3.00 \pm 1.34$ & $\mathrm{~B}$ \\
\hline
\end{tabular}

*means in the same column followed by the same letter do not differ from each other (Tukey test; $p<0.05$ ).

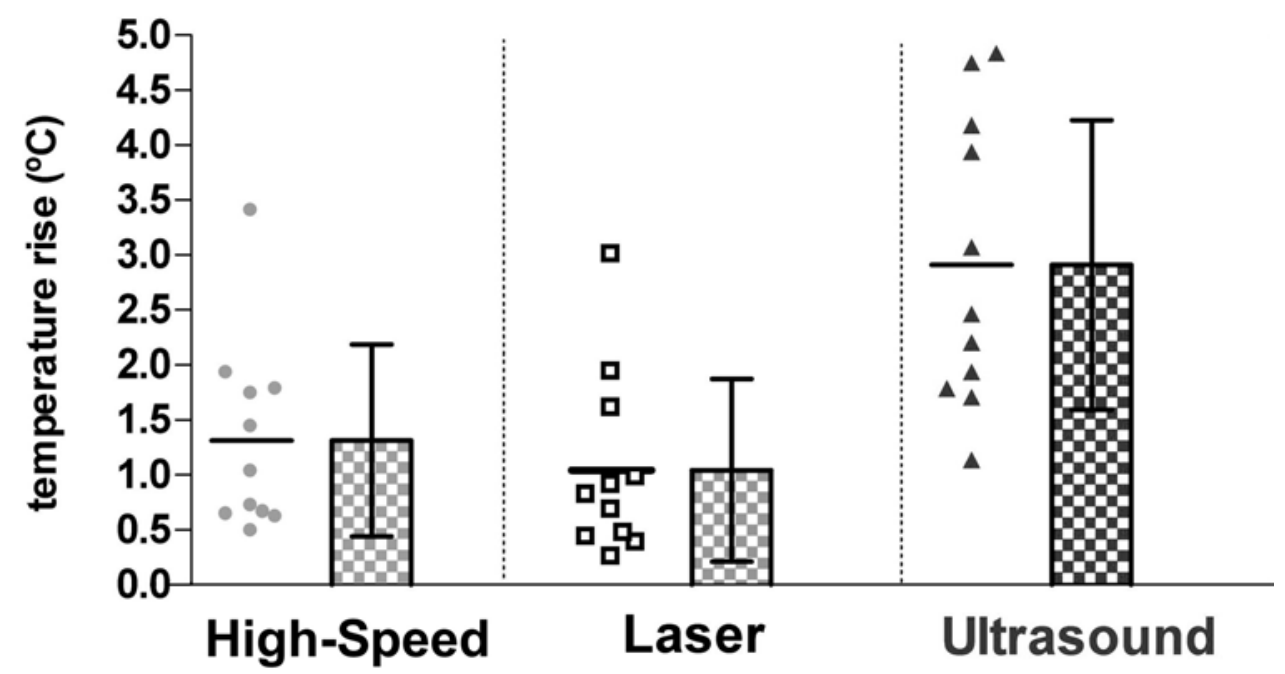

FIGURE 2- Dot plot (around the mean value) and bar columns (mean $\pm \mathrm{sd}$ ) for temperature rise data $\left({ }^{\circ} \mathrm{C}\right)$ by groups

The cavities were prepared with new, round, cylindrical diamond burs (\#1093; KG Sorensen, Barueri, São Paulo, Brazil) measured to a depth of $3.5 \mathrm{~mm}$. A new bur was used for every two cavities. For all specimens, the thickness of the remaining dentin was approximately $0.5 \mathrm{~mm}$, as measured with a periodontal probe.

For Group II specimens, cavities were prepared with an Er:YAG laser (Key III, Kavo, Biberach, Riss, Germany). Laser parameters were as follows: power setting of $3.5 \mathrm{~W}$, energy per pulse of $250 \mathrm{~mJ}$ and frequency of $4 \mathrm{~Hz}$ with pulse duration of $250 \mu \mathrm{s}$. The equipment was used in the noncontact mode, with water coolant flow of $4.5 \mathrm{~mL} / \mathrm{min}$. Cavity depth was defined as approximately $3.5 \mathrm{~mm}$, measured with a periodontal probe every $30 \mathrm{~s}$.

For Group III specimens, the cavities were made using diamond tips (81117, CVDentus, CVDVale, São José dos Campos, SP, Brazil) coupled to an ultrasound device (AE200, Adiel Nac Plus, Ribeirão Preto, SP, Brazil) by an adapter, (UA-01, CVDentus, CVDVale, São José dos Campos, São Paulo, Brazil) to a depth of approximately $3.5 \mathrm{~mm}$, as measured with a periodontal probe. A new tip was used for every two preparations.

The type $\mathrm{T}$ thermocouples were connected to a data acquisition system (model ADS 2000 IP; Lynx Technology), which was linked to a notebook computer (Satellite 2675; Toshiba, Irvine, California, USA) with specific software. Readings were made every $0.125 \mathrm{~s}$. The temperature variation $(\Delta \mathrm{T})$ was determined as the increase from baseline temperature to the highest temperature recorded after starting tooth preparation. Data were analyzed by one-way ANOVA and Tukey's test $(\mathrm{p}=0.05)$.

\section{RESULTS}

The mean temperature rises during cavity preparation were $1.10^{\circ} \mathrm{C}( \pm 0.56)$ for Group I, $0.84^{\circ} \mathrm{C}( \pm 0.55)$ for Group II and $3.00^{\circ} \mathrm{C}( \pm 1.34)$ for Group III. The summarized data are shown in Table I and Figure 2.

There were statistically significant differences among the groups. The null hypothesis was therefore rejected (oneway ANOVA, statistics $\mathrm{F}_{\mathrm{df}(2 ; 27)}=18.2$; $\mathrm{p}$-value $\left.=0.0001<0.05\right)$. Tukey's multiple comparison test showed statistically significant difference $(\mathrm{p}<0.05)$ between Group III (Ultrasound) and the other two groups (Table 1).

\section{DISCUSSION}

Bovine teeth were used in this study because the there is a shortage of human teeth and the literature has demonstrated that bovine dentin is a suitable substitute for human dentin ${ }^{26}$.

In the present study, the temperature rise values during tooth preparation with ultrasound diamond tips were significantly higher than those obtained for high-speed 
handpiece and Er:YAG laser, all under water-cooling.

There are great differences with respect to power settings, frequency, size, and depth of the cavities among studies that evaluated temperature increases during use of the Er:YAG laser $2,6,7,14,18,32$. However, there is consensus about the importance of using water cooling for tooth preparation ${ }^{6,9,18,21}$. The laser parameter settings of this study were established in accordance with the device manufacturer's recommendations. After being tested in sound bovine enamel and dentin, these parameters were considered adequate with respect to temperature control and ablation rate.

Er:YAG laser preparation showed the lowest mean temperature rise. Nevertheless, there was no statistically significant difference between this group and the high-speed handpiece group. These results are in agreement with those of a previous study that showed that pulp response to cavities prepared with Er:YAG laser using air-water spray was minimal, reversible and comparable to the response produced by high-speed handpiece burs ${ }^{28}$. In other in vivo studies $^{5,19}$, there were no significant differences in the histological changes in dentin and pulp tissue, when either Er:YAG laser or high-speed burs were used. Tazikawa ${ }^{30}$, in an in vivo experiment using human teeth, confirmed the safety of Er:YAG laser use during cavity preparation as regards tooth pulp histology. Keller \& $\mathrm{Hibst}^{15}$ and Cozean et al. ${ }^{5}$ reported that after cavity preparation with Er:YAG laser in humans, there was no loss of pulp vitality. Oelgiesser, et al. ${ }^{20}$ found that the use of Er:YAG laser for cavity preparation in enamel, dentin and cement, and for caries removal is a safe procedure with regard to temperature rise, as in all specimens, the pulp chamber temperature rise was below the critical value of $5.5^{\circ} \mathrm{C}^{34}$. Cavalcanti et al. ${ }^{4}$ found no significant difference among the groups prepared with high speed burs and Er:YAG laser, under cooling, and mean temperature variation of $0.96^{\circ} \mathrm{C}$ and $2.69^{\circ} \mathrm{C}$, respectively.

Although Er:YAG laser is considered as safe to pulp vitality, some studies have shown that micro-fractures in enamel may be related to heat generation during irradiation $^{7,13}$, as observed in a scanning electronic microscopy study ${ }^{6}$.

Notwithstanding the fact that CVDentus manufacturer reports that these tips produce little heat, in the present study this was the group produced the greatest temperature rise, compared to the other two groups. Moreover, only one study was found in the literature about this product ${ }^{25}$.

It is assumed that pulp temperature rise during cavity preparation in vivo would be lower than it is in vitro because the presence of pulp tissue with blood circulation and the high water content in vital dental structures could help heat dissipation $^{11}$.

\section{CONCLUSIONS}

The use of Er:YAG laser and high-speed handpiece for cavity prepation resulted in similar temperature increase, but ultrasound tips generated significantly higher intrapulpal temperature rise. Even so, ultrasound preparation did not reach the critical value for temperature increase and may be considered safe for use.

\section{REFERENCES}

1- Armengol V, Jean A, Marion D. Temperature rise during Er:YAG and Nd:YAP laser ablation of dentin. J Endod. 2000;26:138-41.

2- Burkes EJ Jr, Hoke J, Gomes E, Wolbarsht M. Wet Versus dry enamel ablation by Er:YAG laser. J Prosthet Dent. 1992;67:847-51.

3- Cavalcanti BN, Otani C, Rode SM. High speed cavity preparation techniques with different water flows. J Prosthet Dent. 2002;87:15861 .

4- Cavalcanti BN, Lage-Marques JL, Rode SM. Pulpal temperature increases with Er:YAG laser and high-speed handpieces. J Prosthet Dent. 2003;90:447-51.

5- Cozean C, Arcoria CJ, Pelagalli J, Powell Gl. Dentistry for the $21^{\text {st }}$ century? Erbium:YAG laser for teeth. J Am Dent Assoc. 1997; $128: 1080-7$

6- Dostalova T, Jelinkova H, Krejsa O, Hamal H. Evaluation of the surface changes in enamel and dentin due to possibility of thermal overheating induced by Erbium:YAG laser radiation. Scanning Microsc. 1996;10(1):285-90.

7- Glockner K, Rumpler J, Ebeleseder K, Stadtler P. Intrapulpal temperature during preparation with the Er:YAG laser compared to the conventional bur: an in vitro study. J Clin Laser Med Surg. 1998; 16:153-7.

8- Gordon TE Jr. Single-surface cutting of normal tooth with ruby laser. J Am Dent Assoc 1967;74:398-402.

9- Gow AM, McDonald AV, Pearson GJ, Setchell DJ. An in vitro investigation of the temperature rises produced in dentin by Nd:YAG laser light with and without water-cooling. Eur J Prosthodont Restor Dent. 1999;7:71-7.

10 - Hadley J, Young DA, Eversole LR, Gornbein JA. A laser powered hydrokinetic system for caries removal and cavity preparation. J Am Dent Assoc. 2000;131:777-85.

11 - Hannig M, Bott B. In-vitro pulp chamber temperature rise during composite resin polymerization with various light-curing sources. Dent Mater. 1999;15(4):275-81.

12 - Hibst R, Keller U. Experimental studies of the application of the Er:YAG laser on dental hard substances. I. Measurement of the ablation rate. Lasers Surg Med. 1989;9:338-44.

13 - Hoke JA, Burkes EJ Jr, Gomes ED, Wolbarsht ML. Erbium:YAG (2.94 mum) laser effects on dental tissues. J Laser Appl. 1990;2:615 .

14- Keller U, Hibst R. Experimental studies of the application of the Er:YAG laser on dental hard substances. II. Light microscopic and SEM investigations. Lasers Surg Med. 1989;9:345-51.

15 - Keller U, Hibst R. Effects of Er:YAG laser in caries treatment: a clinical pilot study. Lasers Surg Med. 1997;20:32-8.

16- Keller U, Hibst R, Geurtsen W, Schilke R, Heidemann D, Klaiber B, et al. Erbium:YAG laser application in caries therapy. Evaluation of patient perception and acceptance. J Dent. 1998;26:649-56. 
17- Lefkowitz W. Ultrasonics in dentistry. J Am Dent Assoc. 1956;52:406-9

18 - Matsumoto K, Nakamura Y, Mazeki K, Kimura Y. Clinical dental application of Er:YAG laser for class $\mathrm{V}$ cavity preparation. J Clin Laser Med Surg. 1996;14:123-7.

19- Miserendino LJ, Cozean CD. Histological results following in vivo cavity preparation with an Er:YAG laser. In: Featherstone JD, Rechmann P, Fried DS. Lasers in Dentistry, IV. Proceeding SPIE. 1998;3248:46-50

20 - Oelgiesser D, Blasbalg J, Ben-Amar A. Cavity preparation by ErYAG laser on pulpal temperature rise. J Dent. 2003;16:96-8.

21 - Paghdiwala AF. Does the laser work on hard dental tissue? J Am Dent Assoc. 1991;122:79-80.

22- Paghdiwala AF, Vaidyanathan TK, Paghdiwala MF. Evaluation of erbium:YAG laser radiation of hard dental tissues: analyses of temperature changes, depth of cuts and structural effects. Scanning Microsc. 1993;7:989-97.

23 - Peck S, Peck H. Laser radiation: some specific dental effects and an evaluation of its potential in dentistry. J Prosthet Dent. 1967; 17:195-203.

24- Peyton FA. Temperature rise in teeth developed by rotating instruments. J Am Dent Assoc. 1955;50:629-32.

25- Predebon JC, Flório FM, Basting RT. Use of CVDentus diamond tips for ultrasound in cavity preparation. J Contemp Dent Pract. 2006;7:50-8.

26- Schilke R, Lisson JA, Bauss O, Geurstsen W. Comparison of the number and diameter of dentinal tubules in human and bovine dentine by scanning electron microscopic investigation. Arch Oral Biol. 2000;45:355-61.

27- Schuchard A, Watkins CE. Thermal and histologic response to high-speed and ultrahigh-speed cutting in tooth structure. J Am Dent Assoc. 1965;71:1451-8.

28- Sonntag KD, Klitzman B, Burkes EJ, Hoke J, Moshonov J. Pulpal response to cavity preparation with the Er:YAG and Mark III free electron lasers. Oral Surg Oral Med Oral Pathol Oral Radiol Endod. 1996;81:695-702.

29- Swerdlow H, Stanley HR. Reaction of the human pulp to cavity preparation: results produced by eight different operative grinding techniques. J Am Dent Assoc. 1959;58:49-59.

30- Takizawa M. A study on Er:YAG laser ablation for dental hard substance. Jpn J Conserv Dent. 1996;39:1089-128.

31 - Visuri SR, Walsh JT Jr, Wigdor HA. Erbium laser ablation of dental hard tissue effect of water cooling. Lasers Surg Med. 1996;18:294-300.

32- Walsh JT, Flotte TJ, Deutsch TF. Er:YAG laser ablation of tissue: effect of pulse duration and tissue type on thermal damage. Lasers Surg Med. 1989;9:314-26.

33- Wigder HA, Walsh JT, Featherstone JDB, Visuri SR, Fried D, Waldvogel JL. Lasers in dentistry. Lasers Surg Med. 1995;16:103-33.

34- Zach L, Cohen G. Pulp response to externally applied heat. Oral Surg Oral Med Oral Pathol. 1965;19:515-30. 